\title{
ANALISA EFISIENSI PERUSAHAAN TELEKOMUNIKASI DENGAN METODE DATA ENVELOPMENT ANALYSIS (DEA) BERBASIS PENDEKATAN BIAYA
}

(Studi Pada Perusahaan Penyelenggara Telekomunikasi PT Telekomunikasi Indonesia Tbk, PT Indosat Tbk, dan PT XL Axita Tbk)

\author{
Firmansyah ${ }^{1}$ \\ ${ }^{1}$ Tenaga Pengajar Prodi D-III Kebidanan Akademi Kebidanan Assyifa Tangerang \\ Email :fsyah.firman@gmail.com
}

\begin{abstract}
ABSTRAK
Latar Belakang :. Industri telekomunikasi mengalami perkembangan yang pesat sejak dikeluarkannya undang undang telekomunikasi no 36 Tahun 1999 yang mengatur reformasi industri telekomunikasi, termasuk liberalisasi industri, memfasilitasi masuknya pemain baru dan menumbuhkan persingan usaha yang sehat. Untuk mengetahui perusahaan telekomunikasi yang sehat, pengukuran efisiensi menjadi sangat penting. Hal ini dikarenakan efisiensi merupakan gambaran kinerja suatu kegiatan bisnis sekaligus menjadi faktor yang harus diperhatikan untuk bertindak rasional dalam meminimumkan tingkat risiko yang dihadapi dalam menghadapi kegiatan operasionalnya.

Tujuan : Penelitian ini bertujuan untuk mengukur efisiensi relative perusahaan telekomunikasi di Indonesia dengan menggunakan metodologi Data Envelopment Analysis (DEA) berdasarkan pendekatan pengendalian biaya.

Metode Penelitian : Penelitian ini dilakukan pada tiga perusahaan telekomunikasi besar di Indonesia yang menjadi sample penelitian diantaranya adalah PT Telekomunikasi Indonesia Tbk, PT Indosat Tbk, dan PT XL Axiata Tbk. DEA merupakan metodologi dengan pendekatan non paramtrik-deterministik yang bertujuan untuk menentukan eifisiensi relative dan kinerja manajerial, dengan menentukan input dan output suatu UPK (Unit Pengambil Keputusan).

Hasil Penelitian : Hasil penelitian menunjukkan bahwa, PT Telekomunikasi Indonesia merupakan perusahaan telekomunikasi yang relatif efisien selama tahun penelitian, dimana secara teknis, overall, dan skala, tingkat pengukuran efisiensi menghasilkan skore sebesar 100 terkecuali pada tahun 2013 secara skala dan overall hanya sebesar 96,85 .
\end{abstract}

Keywords : Data Envelopment Analysis, Efisiensi dan Pengendalian Biaya

\begin{abstract}
Telecommunications industry experienced a rapid growth since the establishment of the telecommunications act no. $36 / 1999$ which regulates the reformation of telecommunication industry, including the liberalizing industry to facilitate new establisment and and foster healty competition. To recognize a healty telecomunication company, effeciency's measurements plays an important role. This is because efficiency represents the performance of a business activity as well
\end{abstract}


as other factors that must be considered to act rationally to minimize risks in operational activities.

The objective of this research is to measure relative efficiency of telecommunication company in Indonesia by utilizing Data Envelopment Analysis (DEA) based on cost control. Implementation of this research is held on 3 (three) major telecommunication company in Indonesia i.e. PT Telekomunikasi Indonesia Tbk, PT Indosat Tbk and PT XL Axiata tbk. DEA is a methodological approach of non paramtrik-deterministik which aims to determine the relative effisiency and the managerial performance to specify the input and output of a decision making unit.

Research shows that PT Telekomunikasi Indonesia is relatively efficient over the years of research, technically, overall, and scale, the efficiency level measurement produce a score of 100 with the exception in years 2013,scale and overall only reached a score of 96,85 .

\section{Keyword : Data Envelopment Analysis, Efficiency and Cost Control}

\section{PENDAHULUAN.}

Teknologi komunikasi di Indonesia berkembang dengan sangat cepat yang juga dengan serta merta mengubah cara manusia berkomunikasi satu sama lain, baik dalam konteks bisnis maupun bersosialisasi, di mana perkembangan paling pesat ada pada telekomunikasi seluler. Perubahan cara berkomunikasi ini berdampak pada peningkatan penggunaan sarana telekomunikasi yang signifikan

Industri Telekomunikasi merupakan bagian dari network industries yang menyediakan pelayanan transfer data dan suara, seperti telepon dan internet. Karakteristik utama yang umumnya terdapat pada network industries adalah industri dengan biaya investasinya dan biaya operasional yang sangat besar dengan komponen komponennya bersifat komplementer untuk melayani kebutuhan dasar dalam kehidupan sehari yaitu bertelekomunikasi. Industri telekomunikasi di Indonesia mengalami perkembangan yang pesat terutama setelah dikeluarkannya UU No. 36 Tahun 1999 tentang Telekomunikasi. Berdasarkan undang undang tersebut, penyelenggara jasa telekomunikasi meliputi tiga hal yaitu: (1) Penyelenggara jaringan telekomunikasi, (2) Penyelenggara jasa telekomunikasi, dan (3) penyelenggara telekomunikasi khusus

Ketatnya persaingan dalam industri telekomunikasi membuat beberapa operator lebih memilih menggunakan harga sebagai senjata utama untuk merebut konsumen. Tsai, et al. (2006) mengungkapkan bahwa untuk bertahan hidup dalam kompetisi yang sangat ketat ini, perusahaan telekomunikasi bekerja keras memotong biaya untuk menjaga kestabilan keuntungan mereka. Dikarenakan harga jual layanan dan produk yang sangatlah sensitif maka pengendalian biaya perlu dilakukan untuk menghasilkan profit yang diiginkan. Mekanisme ini sejalan dengan yang dijelaskan oleh Anthony and Govindarajan (2007), yaitu efisiensi optimalisasi keuntungan yang dilakukan dengan meminimalkan sumber daya yang digunakan untuk memperoleh tingkat hasil tertentu.

Perkembangan pesat pada industri telekomunikasi menciptakan persaingan yang ketat pada industri tersebut dalam hal harga jual produk dan layanan. Industri telekomunikasi merupakan industri dengan biaya investasi modal dan biaya operasional 
yang tinggi. Industri telekomunikasi memiliki segementasi pasar dan jenis layanan yang sama berakibat pada harga jual produk dan layanan yang tidak dapat terlalu tinggi dengan perusahaan yang lainya. Industri telekomunikasi perlu melakukan efisiensi dalam hal pengendalian biaya-biaya (cost control) untuk kelangsungan usaha dan dapat bersaing untuk menciptakan laba bersih usaha yang positif.

Efisiensi dalam kaitannya dengan pengendalian biaya dengan variabel penelitian yang berhubungan dengan tenaga kerja, total aktiva, kinerja laba, dan efektivitas pemasaran. Metode yang digunakan adalah Data Envelopment Analysis (DEA). Sampel objek penelitian terdiri dari tiga perusahaan telekomunikasi yang terdaftar pada bursa Efek Indonesia (BEI), yaitu pada data laporan keuangan konsolidasian tahun 2009 sampai dengan tahun 2013.

Permasalahan pokok pada penelitian ini dibatasi pada hal-hal yang berkaitan dengan kondisi efisiensi perusahaan telekomunikasi dari tahun 2009-2013 menggunakan Metode DEA berbasis pendekatan biaya, menganalisis perusahaan Telekomunikasi yang lebih efisien selama periode tahun 20092013 tersebut dan menganalisis penyebab inefisensi pada perusahaan Telekomunikasi berbasis pendekatan biaya.

\section{METODE PENELITIAN}

Penelitian ini adalah penelitian empiris yang meneliti efisiensi perusahaan telekomunikasi di Indonesia, di mana penelitian ini menggunakan metode Data Envelopment Analysis (DEA) untuk mengukur tingkat efisiensi perusahaan telekomunikasi di Indonesia selama periode tahun 2009 sampai dengan tahun 2013. Metode DEA adalah model matematis pemrograman linear yang mengubah input dan output yang beragam menjadi satu pengukuran kinerja yang menyeluruh Tsai, et al. (2006).

Penelitian dilakukan terhadap data laporan keuangan konsolidasian (neraca dan laporan laba-rugi) perusahaan induk dan entitas anaknya yang terdaftar pada bursa efek indonesia periode 2009-2013 yang diperoleh melalui situs resmi Bursa Efek Indonesia (BEI), www.idx.co.id. Penelitian dilakukan mulai bulan Juni 2014 sampai dengan bulan Mei 2015. Jenis penelitian yang digunakan adalah penelitian kuantitatif dengan pendekatan nonparametrik. Pendekatan nonparametrik memakai metode DEA untuk mengukur tingkat efisiensi suatu unit pengambilan keputusan (UPK).

Objek dalam penelitian ini adalah laporan keuangan yang di publikasikan terhadap tiga perusahaan telekomunikasi yang ada di Indonesia pada tahun 2009 sampai dengan tahun 2013 untuk mengukur efisiensi pada tiga perusahaan tersebut. Teknik pengambilan sampel yang digunakan adalah purposive sampling, sampel penelitian yang dapat mewakili populasi yaitu PT Telekomunikasi Indonesia Tbk, PT Indosat Tbk, dan PT XL Axiata Tbk, yang terdaftar di Bursa Efek Indonesia.

Penelitian ini menggunakan data sekunder yang diperoleh dari laporan keuangan tahunan Perusahaan Telekomunikasi di Indonesia pada periode 2009-2013 yang terdiri dari : Total Aktiva yang diperoleh dari neraca dalam laporan keuangan konsolidasian tahunan selama periode pengamatan. Beban Pemasaran diperoleh dari laporan laba/rugi dalam laporan keuangan konsolidasian tahunan selama periode pengamatan. Beban Karyawan yang diperoleh dari laporan laba/rugi dalam laporan keuangan konsolidasian tahunan selama periode pengamatan.

Pendapatan yang diperoleh dari laporan laba/rugi dalam laporan keuangan kondolidasian tahunan selama periode 
pengamatan. Laba Usaha diperoleh dari laporan laba/rugi dalam laporan keuangan konsolidasian tahunan selama periode pengamatan. Ebitda diperoleh dari Annual Report yang dipublikasikan selama periode pengamatan. Metode yang digunakan dalam penelitian ini adalah Data Envelopment Analysis (DEA). Dimana pada tahap pengolahan data peneliti menggunakan software Banxia Frontier Analyst 3.

\section{HASIL DAN PEMBAHASAN}

Objek pada penelitian ini adalah beberapa perusahaan telekomunikasi di Indonesia dengan rentang waktu penelitian dari tahun 2009-2013. Jumlah perusahaan telekomunikasi yang menjadi unit pengambilan keputusan (UPK) adalah berjumlah tiga perusahaan diantaranya adalah PT Telekomunikasi Indonesia Tbk, PT Indosat dan PT XL Axiata. telah memenuhi kriteria penelitian sebagaimana terlah tercantum pada bab sebelumnya. Ketiga perusahaan tersebut adalah PT Telekomunikasi Indonesia Tbk, PT Indosat Tbk, dan PT XL Axita Tbk.

Data sampel menunjukkan bahwa data yang digunakan dalam penelitian ini bersifat cross section dan sudah lengkap dari tahun ke tahun (time series). Data PT Telekomunikasi Indonesia, PT Indosat, dan PT XL Axiata tersedia dari tahun 2009-2013 untuk setiap variabel, oleh karenanya ketiga perusahaan telekomunikasi seluler ini berikut tahun penelitiannya dapat disebut dengan UPK (Unit Pengambilan Keputusan) atau disebut juga dengan DMU (Decision Making Unit). Sehingga, dalam penelitian ini memiliki 15 UPK.

Dalam penelitian ini diasumsikan perusahaan telekomunikasi seluler memiliki variabel output yang digunakan dalam penelitian ini adalah Pendapatan (Y1), EBTIDA (Y2) dan Laba Operasi (Y3), sementara variabel input terdiri dari Total Aktiva (X1), Beban Pemasaran (X2), dan Beban Karyawan (X3). Dengan menggunakan Software Banxia Frontier Analyst 3 suatu DMU akan dinyatakan telah mencapai efisiensi relative jika mencapai skor 1 atau $100 \%$ dan semakin tidak efisien jika semakin jauh dari nilai 1 atau $100 \%$. Berikut diurai nilai efisiensi Perusahaan Telekomunikasi Seluler di Indonesia berdasarkan hasil pengolahan DEA.

Tabel 1.1 Tingkat Efisiensi Perusahaan Telekomunikasi Seluler

\begin{tabular}{lcccl}
\hline \multicolumn{1}{c}{ DMU } & CRS & VRS & Scale & RTS \\
\hline 2013PT XL AXIATA & 100 & 100 & 100 & constant \\
2012PT XL AXIATA & 100 & 100 & 100 & constant \\
2012PT INDOSAT & 100 & 100 & 100 & constant \\
2010PT XL AXIATA & 100 & 100 & 100 & constant \\
2013PT INDOSAT & 100 & 100 & 100 & constant \\
2009PT TELEKOMUNIKASI INDONESIA & 100 & 100 & 100 & Constant \\
2011PT TELEKOMUNIKASI INDONESIA & 100 & 100 & 100 & Constant \\
2010PT TELEKOMUNIKASI INDONESIA & 100 & 100 & 100 & Constant \\
2012PT TELEKOMUNIKASI INDONESIA & 99.85 & 100 & 99.85 & Constant \\
2013PT TELEKOMUNIKASI INDONESIA & 96.85 & 100 & 96.85 & Constant \\
2011PT XL AXIATA & 93.69 & 99.29 & 94.36 & Decreasing \\
2009PT INDOSAT & 92.50 & 100 & 92.50 & Constant \\
2010PT INDOSAT & 91.41 & 95.41 & 95.81 & Decreasing \\
2011PT INDOSAT & 89.55 & 100 & 89.55 & Constant
\end{tabular}




\section{PT XL AXIATA}

84.87

\section{0}

Sumber : Diolah dari software Banxia Frontier Analyst 3

Berdasarkan tabel 1.1, maka terdapat 8 DMU dari 15 DMU yang efisien secara skala dan overall. Adapun secara teknis, terdapat 13 DMU yang sudah efisien. Sedangkan sisanya, 2 DMU lainnya menunjukkan skor diatas $80 \%$ artinya rata-rata keseluruhan DMU sudah menunjukkan tingkat efisiensi yang cukup baik.

Kolom RTS (Return to Scale) menunjukkan kondisi masing-masing DMU berdasarkan perolehan efisiensi, dimana DMU dengan tingkat score efisiensi 100 kondisi RTS adalah constant. Hal ini berarti bahwa DMU yang berada dalam kondisi constant sudah efisien $100 \%$ dan dapat melanjutkan kegiatan produksinya karena dianggap sudah efisien dan tidak ada lagi yang perlu diperbaiki.

Sedangkan kondisi DMU yang belum efisien (memiliki nilai score < 100\%), kemungkinan dapat berada dalam salah satu diantara dua kondisi, IRS (Increasing) dan DRS (Decreasing). DMU yang berada dalam kondisi IRS memungkinkan untuk terus meningkatkan kapasitas output-nya dengan mempertahankan input yang ada, karena penambahan input justru tidak efektif mengingat sumber daya yang digunakan masih belum berfungsi secara optimal. Adapun DMU yang berada dalam kondisi DRS (Decreasing) menuntut adanya pengurangan input, karena jumlah input dengan output yang dihasilkan sudah tidak ideal.

Hasil pengolahan menunjukkan bahwa 2 DMU berada dalam kondisi DRS yang dinotasikan dengan angka dibawah 100. Sedangkan sisanya 13 DMU yang berada dalam kondisi efisien yang ditunjukkan dengan angka 100 (lihat tabel 1.1). Adapun 2 DMU yang berada pada kondisi DRS menuntut adanya pengurangan input, karena jumlah input dengan output yang dihasilkan sudah tidak ideal.

Berdasarkan pengolahan terhadap laporan keuangan dari 3 (tiga) Perusahaan Telekomunikasi Seluler, dengan tahun penelitian dari tahun 2009-2013, dapat diketahui Perusahaan Telekomunikasi Seluler yang paling efisien dan inefisien. Pengukuran secara teknis menunjukkan bahwa PT Telekomunikasi Indonesia merupakan Perusahaan Telekomunikasi Seluler yang paling efisien dari tahun ke tahun, yakni $100 \%$ sepanjang tahun 20092013.

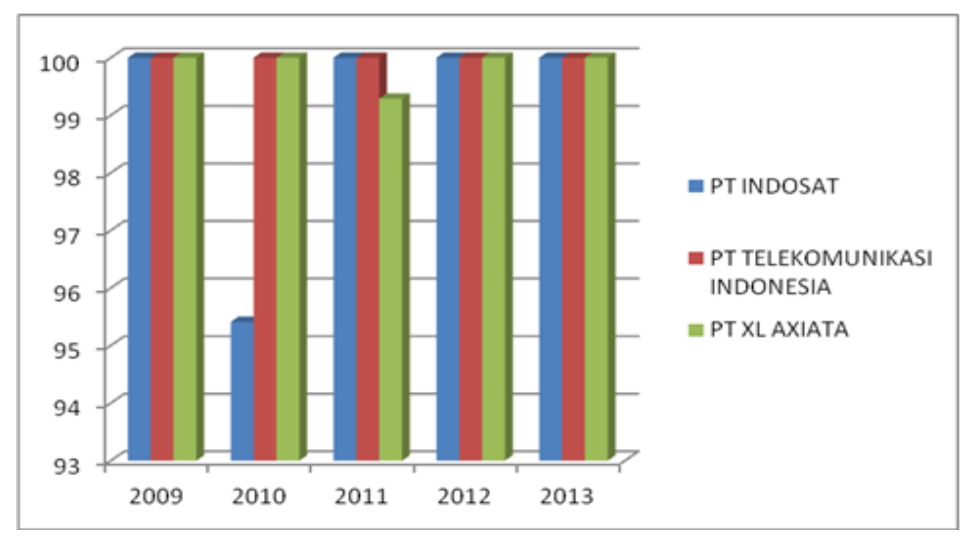

Gambar 1.1 Perbandingan Efisiensi Teknis 
Terdapat dua DMU yang tidak efisien secara teknis berada dalam kondisi decreasing tahun 2010 dan 2011, dimana penambahan input tidak dapat menambah output yang sama besarnya atau lebih besar. Oleh karenanya, diperlukan pengurangan input hingga mencapai titik Constant Return to Scale (CRS).
Adapun perhitungan secara skala menunjukkan bahwa Perusahaan Telekomunikasi Seluler yang berada dalam kondisi efisien selama tahun penelitian adalah PT Telekomunikasi Indonesia, kecuali pada tahun 2013 (lihat gambar 1.2). Efisiensi skala menunjukkan dengan input minimal, PT Telekomunikasi Indonesia dapat menghasilkan output yang lebih besar.

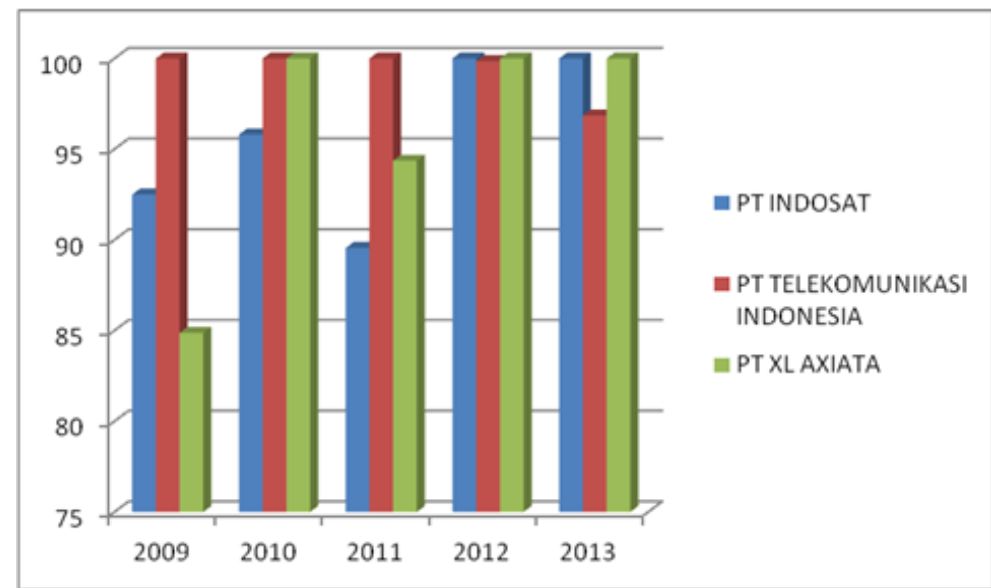

Gambar 1.2 Perbandingan Efisiensi Skala

Tidak jauh berbeda dengan hasil perhitungan secara skala, perhitungan secara overall menunjukkan bahwa Perusahaan Telekomunikasi Seluler yang paling efisien juga ditunjukkan oleh PT Telekomunikasi Indonesia, kecuali pada tahun 2013 (lihat gambar 1.3).

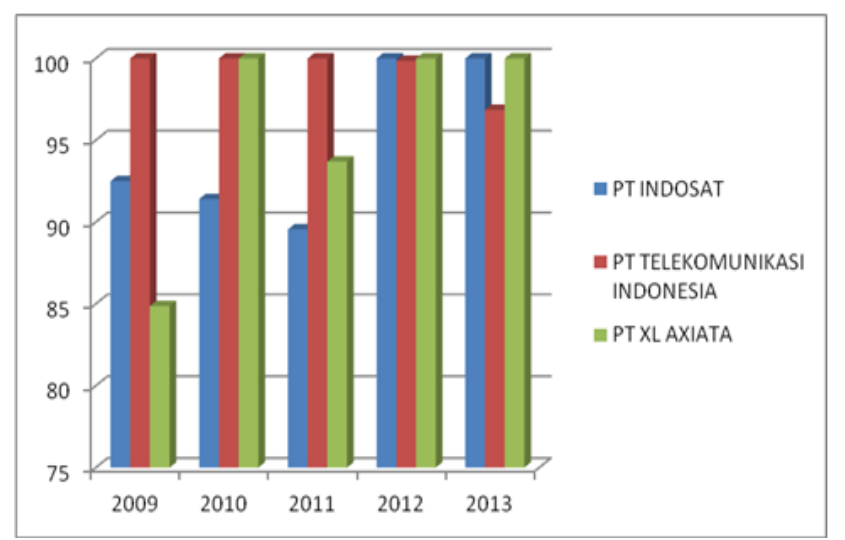

Gambar 1.3 Perbandingan Efisiensi Overall
Tingginya angka efisiensi baik secara overall, teknis dan skala pada PT Telekomunikasi Indonesia menjadikan PT Telekomunikasi Indonesia sebagai benchmark bagi perusahaan telekomunikasi seluler lainnya yang tidak efisien.

Satu keunggulan lainnya yang dimiliki oleh DEA adalah dapat membuat peringkat DMU yang dapat dijadikan benchmark bagi DMU lainnya. Dalam hal ini, dapat memberikan informasi tentang Perusahaan Telekomunikasi Seluler yang paling banyak dirujuk oleh Perusahaan Telekomunikasi Seluler lain yang tidak efisien selama tahun penelitian yaitu 2009-2013.

Berdasarkan reference set yang ditemukan maka pada tahun 2009 sampai dengan tahun 2013 menunjukkan terdapat dua Perusahaan Telekomunikasi Seluler yang sudah efisien dan banyak menjadi rujukan perusahaan yang lain, yaitu PT Telekomunikasi Indonesia Tbk dan PT XL Axiata Tbk, adapun PT Indosat Tbk Indonesia belum bekerja pada titik efisiensi 
yang optimal. Inefisiensi pada PT Indosat Tbk dapat disebabkan oleh penggunaan input yang berlebihan yaitu dari penggunaan aktiva, beban pemasaran, dan beban karyawan.

Sumber utama inefisiensi per Perusahaan Telekomunikasi Seluler dengan pendekatan pengendalian biaya bahwa mayoritas Perusahaan Telekomunikasi Indonesia yang kurang efisien bersumber dari penggunaan aktiva atau kepemilikan aktiva yang terlalu besar yang merupakan kompenen investasi perusahaan yang sangat mahal dan merupakan modal dalam aktivitas usaha pada perusahaan telekomunikasi. Oleh karenanya senada dengan hasil potential improvement secara industri dimana penggunaan aktiva harus dikurangi sebesar $29.41 \%$, beban pemasaran dikurangi sebesar $25.39 \%$, dan beban karyawan dikurangi hingga $19.34 \%$. Sedangkan dari sisi output, laba operasi ditingkatkan sebesar $16.11 \%$, EBTIDA ditingkatkan sebesar $9.45 \%$ dan pendapatan ditingkatkan sebesar $0.29 \%$.

Mayoritas perusahaan telekomunikasi secara gabungan pada industri perusahaan telekomunikasi seluler yang diteliti bahwa untuk mengatasi inefisiensi langkah langkah yang harus dilakukan dari sisi input adalah penggunaan aktiva harus dikurangi sebesar $29.41 \%$, beban pemasaran dikurangi sebesar $25.39 \%$, dan beban karyawan dikurangi hingga $19.34 \%$. Sedangkan dari sisi output, laba operasi ditingkatkan sebesar $16.11 \%$, EBTIDA ditingkatkan sebesar $9.45 \%$ dan pendapatan ditingkatkan sebesar $0.29 \%$.

\section{KESIMPULAN}

1. Efisiensi perusahaan telekomunikasi secara gabungan di Indonesia memperlihatkan hasil efisien pada tahun tahun penelitan, dimana secara teknis hampir sepanjang tahun penelitian menujukan skor 100 yang berarti efisien, terkecuali di tahun 2010 dan 2011 secara teknis menunjukkan skor 99,29 dan
95,41 masih dalam kriteria cukup efisien. Tingginya tingkat efisiensi secara teknis menunjukkan bahwa kinerja perusahaan telekomunikasi sudah cukup baik dalam memperoleh output yang diharapkan berupa pendapatan, laba operasi dan Ebtida yang memperlihatkan nilai yang positif dengan input yang digunakan.

2. Secara keseluruhan perusahaan telekomunikasi yang lebih efisien dan banyak dijadikan rujukan oleh perusahaan telekomunikasi lainnya pada tahun-tahun penelitian yaitu PT Telekomunikasi Indonesia Tbk pada tahun 2009, tahun 2010 dan tahun 2011, PT Indosat pada tahun 2012 dan di tahun 2013.

3. Faktor Utama penyebab inefisiensi dalam kaitannya dengan pengendalian biaya terlihat pada tidak optimalnya penggunaan aktiva dalam perusahaan sehingga besarnya alokasi belanja modal terutama untuk pembangunan infrasturuktur perusahaan telekomunikasi belum memperlihatkan output yang sebanding yaitu kurang optimalnya laba yang dihasilkan dikarenakan besarnya investasi, beban operasional, beban penyusutan dan amortisasi pada aktiva tetap tersebut.

\section{SARAN}

1. Untuk dapat mempertahankan sustainabilitasnya, perusahaan perusahaan telekomunikasi di Indonesia khususnya pada PT Telekomunikasi Indonesia Tbk, PT Indosat Tbk, dan PT XL Axita untuk dapat terus memperbaiki kinerjanya. Perbaikan kinerja ini dapat dilakukan dengan memperbaiki sumber utama inefiseiensi yaitu penggunaan input dalam hal penggendalian biaya. Dalam hal ini PT Telekomunikasi Indonesia Tbk, PT Indosat Tbk dan PT XL Axiata untuk tahun tahun berikutnya tidak melakukan pembangunan menaramenara BTS dan beralih kepada sewa menara langkah ini dilakukan untuk lebih selektif dalam alokasi biaya modal serta 
mengurangi beban operasional yaitu biaya depresiasi dari aktiva tetap tersebut.

2. Ditengah kompetisi yang semakin ketat dalam menyambut era $4 \mathrm{G}$ industri telekomunikasi hendaknya perusahaan telekomunikasi dapat berkerjasama untuk saling berbagi infrastruktur seperti roaming jaringan, radio access network dan jaringan utama termasuk kabel serat optik atau tembaga. Sehingga masingmasing perusahaan telekomunikasi tidak melakukan pengadaan secara sendirisendiri.
3. Perbaikan dari sisi peningkatan pendapatan dapat dilakukan oleh perusahaan Telekomunikasi di Indonesia dengan meningkatkan layanan jasa kepada pelanggan berupa perbaikan jaringan, kualitas jangkauan sinyal serta akses internet pengiriman data yang merupakan usaha-usaha dalam mempertahankan pelanggan dan tidak lagi terfokus pada penambahan jumlah pengguna kartu perdana yang diterbitkan.

\section{DAFTAR PUSTAKA}

Aam Slamet Rusydiana, dkk. 2013. Mengukur Tingkat Efisiensi Dengan Data Envelopment Analysis (DEA): Teori Dan Aplikasi. SMART Publishing

Abidin, Zaenal. 2007. Kinerja Efisiensi Pada Bank Umum. Universitas Gunadarma Proceeding PESAT Vol. 2 ISSN: $1858-$ 2559.

Akbar, Nasher. 2009. Analisis Efisiensi Organisasi Pengelola Zakat Dengan Pendekatan Data Envelopment Analysis. Sekolah Tinggi Ekonomi Islam Tazkia, Bogor.

Ascarya dan Yumanita, 2006, Analisis Efisiensi Perbankan Syariah di Indonesia dengan Data Envelopment Analysis. TAZKIA Islamic Finance and Business Review, Vol.1, No.2, Desember 2006.

Coelli, Timothy J., D.S Prasada Rao, Christopher J. O'Donnell dan George E.Battese. An Introduction to Efficiency and Productivity Analysis. Edisi Kedua. Springer. 2005.

Daljono. 2009. Akuntansi Biaya: Penentuan Harga Pokok dan Pengendalian. Semarang: Badan.Penerbit Universitas Diponegoro.
Feroz, E. H., Kim, S., \& Raab, R. L. (2003). Financial Statement Analysis: A Data Envelopment Analysis Approach. Journal of Operational Research Society , 54, 45-58.

Ghozali, Imam, 2014. An Efficiency Determinant of Banking Industry in Indonesia. Research Journal of Finance and Accounting Vol 5 No 3.

Huri, Mumu Daman dan Indah Susilowati. 2004. Pengukuran Efisiensi Relatif Emiten Perbankan Dengan Metode Data Envelopment Analysis (DEA). Dinamika PEMBANGUNAN Vol 1 No. 2 / Desember 2004: 95 - 110.

Hafid, A. R. 2007. Peranan Anggaran Biaya Operasi dalam Menunjang Efektivitas pengendalian Biaya Operasi. www.google.com

Hansen, D. R. dan M. M. Mowen. 2009. Akuntansi Manajerial. Jakarta: Salemba Empat.

Kasiram, Mohammad, 2010. Metodologi Penelitian Kualitatif-Kuantitatif, Malang UIN-Maliki Press. 
Kasmir, SE, M.M. 2004. Bank dan Lembaga Keuangan Lainnya. Jakarta: PT. Rajawali Pers.

Kumbhakar, S.C dan Lovell. The Measurement of Technical Efficiency. Journal of The Royal Statistical Society. 2000 .

Kusmargiani, Ida Safitri. 2006. Analisis Efisiensi Operasional Dan Efisiensi Profitabilitas Pada Bank Yang Merger Dan Akuisisi Di Indonesia. Universitas Diponegoro

Kieso, D. E., Weygandt, J. J., \& Warfield, T. D. (2005). Intermediate Accounting (11th ed.). Massachusetts: John Wiley \& Sons.

Kompas. (2008, Februari 29). Perang Tarif, Bahayakan Perusahaan.

Maharani, Fitria. 2012. Pengukuran Efisiensi Perbankan Dengan Menggunakan Pendekatan Data Enbelopment Analysis (DEA) dan Pengaruh Efisiensi Perbankan Terhadap Stock Return Pada Bank Umum Konvensional Yang Terdaftar Di Bursa Efek Indonesia Periode 2005 -2010. Universitas Indonesia, Depok.

Muharam, H dan Rizki Pusvitasari, 2007. Analisis Perbandingan Efisiensi Bank Syariah dengan Metode Data Envelopment Analysis (Periode tahun 2005). Jurnal Ekonomi dan Bisnis Islam, Vol 2 No 3.

Mulyadi. 2007. Sistem Akuntansi. Cetakan Keempat. Jakarta: Salemba Empat.

Mulyadi, Joko Siswanto, 2001, Akuntansi Biaya 1: Kanisius

Purwanto, Rakhmat (2011). Analisis Perbandingan Efisiensi Bank Umum Konvensional (BUK) dan Bank Umum Syariah (BUS) di Indonesia dengan metode Data Envelopment Analysis
(DEA) (Periode 2006-2010). Fakultas Ekonomika dan Bisnis Universitas Diponegoro Semarang.

Putri, Vicky Rahma dan Niki Lukviarman. 2008. Pengukuran Kinerja Bank Komersial Dengan Pendekatan Efisiensi: Studi Terhadap Perbankan Go Public Di Indonesia. JAAI Volume 12 No. 1, Juni 2008

PT Bursa Efek Indonesia. (13 Februari 2014). Bursa Efek Indonesia. Dipetik Maret 2014, dari BursaEfe Indonesia:

http://202.155.2.90/corporate_actions/N ew_Info_JSX/Jenis_Informasi/01_Lapor an_Keuangan/02_Soft_Copy_Laporan_ Keuangan/Laporan\%20Keuangan\%20T ahun\%202008/

Sartono, Agus. (2008), Manajemen Keuangan Teori dan Aplikasi. BPFE: Yogyakarta

Siamat, Dahlan, 2005. Manajemen Lembaga Keuangan Kebijakan Moneter dan Perbankan: Edisi Kelima. Jakarta: Lembaga Penerbit Fakultas Ekonomi Universitas Indonesia.

Sucipto. 2003. Penilaian Kinerja Keuangan. Jurnal Akuntansi. Universitas Sumatera Utara.

Saheruddin, Herman. 2008, Model dan Metodologi Data Envelopment Analysis (DEA) Dalam Analisis Efisiensi dan Produktivitas, Universitas Indonesia

Thantawi, As. 2007. Pengantar Manajemen. Biro Penerbitan FE UB:Malang

Undang-Undang Republik Indonesia Nomor 36 Tahun 1999 Tentang Telekomunikasi.

Wikimedia Foundation, Inc. (24 Juli 2010). Telekomunikasi Seluler di Indonesia. Dipetik

Agustus 2014, dari Wikipedia: http://id.wiki pedia.org/wiki/Telekomunikasi_seluler 